\title{
DIALEKTIKA PESANTREN DAN RADIKALISME DI PESISIR UTARA LAMONGAN
}

\author{
Mujib Ridlwan \\ Sekolah Tinggi Agama Islam Al Hikmah Tuban \\ Email: cak_mujib_ridlwan@yahoo.com
}

\begin{abstract}
This article wants to explain about the dialectics of pesantren and radicalism by taking place in the region of Lamongan Regency. The National CounterTerrorism Agency (BNPT) had announced that there were dozens of pesantren from thousands of pesantren in Indonesia indicated to be involved in recruiting radical santri, including one in Lamongan. But the announcement of the BNPT caused an assessment to be generalized towards all pesantren in Indonesia by foreign observers, that all (not some) pesantren in Indonesia teach radicalism. Evil acts committed by a handful of people cause many other people to be affected. In fact, pesantren which are accused of being indicated to teach radicals also deny that they teach radicals. What exactly is the pesantren dialectic and radicalism and what kind of pesantren teach radicalism? The results of interviews and field findings can prove whether there really is pesantren dialectic and radicalism.
\end{abstract}

\section{Keywords: Islamic Boarding School, Radicalism, Caregiver's Role}

\begin{abstract}
Abstrak
Artikel ini ingin menjelaskan tentang dialektika pesantren dan radikalisme dengan mengambil tempat di wilayah Kabupaten Lamongan. Badan Nasional Anti Terorisme (BNPT) telah mengumumkan bahwa ada puluhan pesantren dari ribuan pesantren di Indonesia yang diindikasikan terlibat dalam menyemai radikalisme di tanah air, termasuk salah satunya di Lamongan. Oleh pengamat asing, pengumuman BNPT itu menyebabkan terjadinya generalisasi terhadap semua pesantren di Indonesia, bahwa semua (bukan beberapa) pesantren di Indonesia mengajarkan radikalisme. Tindakan jahat yang dilakukan oleh segelintir orang menyebabkan banyak orang lain terpengaruh. Bahkan, pesantren yang dituduh diindikasikan mengajar kaum radikal juga menyangkal bahwa mereka mengajar para radikal. Apakah sebenarnya terjadi dialektika antara radikalisme dan pesantren?. Hasil wawancara dan temuan empiris dapat membuktikan apakah memang ada dialektika dan radikalisme pesantren.
\end{abstract}

\section{Kata Kunci: Pesantren, Radikalisme, Peran Pengasuh}




\section{A. Pendahuluan}

Pesantren dan radikalisme, dua hal yang belakangan sering disebut beriringan, menyusul stigma sebagian masyarakat bahwa terjadinya tindak radikal, salah satunya disebabkan dari hasil pengajaran di pesantren. Muhammad Kosim (2006) menjelaskan bahwa stigma negatif yang dialamatkan kepada pesantren itu semakin kuat, ketika Muhammad Yusuf Kallasaat menjabat wakil Presiden RI di era Presiden RI, Susilo Bambang Yudhoyono mengatakan bahwa pesantren perlu diawasi dengan ketat, karena Yusuf Kalla memiliki keyakinan bahwa aksi teror bom Bali tidak tertutup kemungkinan dilakukan oleh santri atau mantan santri. Amrozi dan Ali Ghufron alias Mukhlas dinyatakan bersalah dan dinyatakan sebagai pelaku peledakan bom di Bali pada 12 Oktober 2002, sebagaimana dilansir Majalah Tempo (29 Januari 2004) bahwa kakak-adik yang berasal dari Desa Tenggulun, Kecamatan Solokuro (sebelumnya masuk Kecamatan Paciran), Kabupaten Lamongan itu tercatat sebagai orang yang pernah nyantri di Pondok Pesantren Al-Mukmin Ngruki, Solo yang diasuh Abu Bakar Ba'asyir. Ketika terlibat aksi Bom Bali I, keduanya masih berstatus dalam bimbingan Abu Bakar Ba'asyir.

Pernyataan Yusuf Kalla itu membuat lirikan negatif masyarakat dunia tertuju pada pesantren semakin tajam, seiring semakin banyaknya tindakan terorisme di belahan dunia. Bahkan stigma yang mengatakan pondok pesantren menjadi sarang teroris terus mengalami perkembangannya. Tentu stigma negatif ini membuat masyarakat pesantren termasuk kiai dari pesantren merasa dirugikan, sebagaimana disampaikan Aom Karomani dalam nu.or.id bahwa pesantren yang berada dibawah naungan Nahdlatul Ulama (NU) dan yang berafiliasi kepada NU menjadi bagian dari pesantren yang dirugikan. Karena sesungguhnya tudingan pesantren mengajarkan radikalisme itu hanya ditujukan kepada pesantrenpesantren yang selama ini meneruskan ideologi anti-Pancasila dengan merongrong NKRI. Sementara pesantren-pesantren yang berdiri di bawah organisasi NU atau yang memiliki ikatan dengan NU, tidak pernah melakukan radikalisme apalagi mengajarkannya, karena pesantren-pesantren NU atau yang berafiliasi dengan NU yang jumlahnya ribuan di Indonesia mengajarkan paham moderat-bahkan membenci dan memerangi radikalisme dan terorisme. 
Di sepanjang pesisir utara Lamongan selain pesantren Al Ikhlas yang berlokasi di Desa Sedayu Lawas, Kecamatan Brondong juga terdapat pesantren Al Islam di Desa Tenggulun, Kecamatan Solokuro yang menjadi perhatian masyarakat, terutama terkait ketika membicarakan terorisme. Sedangkan pondok pesantren laindi Pesisir Utara Lamongan memiliki memiliki kecenderungan untuk moderat. Inilah yang memantik peneliti untuk meneliti apakah terjadi dialektika pesantren dengan radikalisme di wilayah pantai utara Lamongan. Dari latar belakang tersebut, muncul pertanyaan penting untuk dijawab yaitu bagaimana dialektika pesantren dan radikalisme di pantai utara Lamongan.

\section{B. Landasan Teori}

\section{Dialektika Pesantren dan Radikalisme}

Istilah dialektika sebenarnya sudah lama muncul, yang pertama kali dibawa dan diperkenalkan oleh Marx (Doyle Paul Johnson dalam M.Z Lawang: 1986) untuk memahami dunia sosial yang banyak dipengaruhi oleh pemikiran Hegal. Pemaknaan dialektika mendapat penegasan dari Engels, yang mengatakan, bahwa Hegel setidaknya memiliki beberapa kaidah untuk bisa mengatakan 'dialektika'. Robert H Lauer dalam Thohir Yuli Kusmanto (2015) mengatakan:

"Pertama, setiap sesuatu yang ada ditandai oleh kesatuan dan konflik dengan lawannnya. Kedua, dalam kehidupan sosial, kontradiksi dapat dilihat dalam pertentangan antara kekuatan-kekuatan dan hubunganhubungan produksi dalam masyarakat kapitalis. Dalam situasi seperti itu, maka kontradiksi merupakan satu kesatuan dalam konflik antara kekuatankekuatan yang berlawanan. Keduanya tidak terelakkan dipersatukan di dalam masyarakat yang sama, tetapi saling konflik satu sama lain. Ketiga, kontradiksi menjadi mekanisme yang menggerakkan perubahan, karena kontrakdiksi tidak dapat dipertahankan untuk jangka waktu yang waktu yang tidak terbatas".

Kaidah pertama di atas, bisa dilihat pada radikalisme yang dialamatkan kepada pesantren. Satu sisi pesantren mendapatkan stigma sebagai lembaga yang mengajarkan radikalisme, tetapi sebagain pesantren lainnya, justru mengambil peran berlawanan yaitu menentang radikalisme atau deradikalisasi. Sebagaimana kaidah pertama di atas, "setiap sesuatu yang ada ditandai oleh kesatuan dan konflik dengan lawannya." 
Selanjutnya Ritzer (George Ritzer dalam Saut Pasaribu, 2014) memberikan penegasan, bahwa dialektika merupakan bagian dari teori kritik, yang memberikan penjelasan bahwa pendekatan dialektis adalah pendekatan yang fokus pada totalitas sosial. Untuk memahami sosial, bukan hanya dipahami secara parsial dari elemen-elemen di masyarakat, Ritzer menyebutnya tidak ada aspek parsial kehidupan dan tidak ada fenomena terpencil yang dapat dipahami jika tidak terkait dengan keseluruhan historis, dengan struktur sosial yang dibayangkan sebagai entitas global.

Pendekatan dialektika ini oleh George Ritzer disebut sebagai pendekatan yang meminta perhatian antarhubungan dari berbagai level realitas sosial, dan tidak kalah penting adalah kesadaran individu, superstruktur budaya, dan struktur ekonomi. Bukan hanya itu, pendekatan dialektika juga mengusung resep metodologis, yaitu satu komponen kehidupan sosial tidak dapat dipelajari secara terpisah dari komponen-komponen lainnya.

Konsepsi meotodologis itu sangat tepat jika diterapkan pada kajian radikalisme di obyek penelitian ini. Tindakan kegiatan radikal, tidak hanya bisa dilihat dari factor ekonomi, budaya saja, tetapi pendidikan dalam hal ini pondok pesantren yang memberikan pengaruh kepada individu-individu pelaku radikal juga harus dilihat. Karena kajian sosial tidak bisa dilihat dari sudut yang parsial, tetapi harus dilihat secara utuh dari komponen-komponen yang terdapat di tengahtengah masyarakat. Penyebab terjadinya tindak radikal di masyarakat dengan pendekatan dialektika ini bisa dilihat dari berbagai sudut pandang, misalnya. Antarhubungan komponen-komponen masyarakat menjadi perhatian dalam satu totalitas, inilah yang oleh George Ritzer disebut sebagai Sinkronik. Sementar Bauman dalam Saut Pasaribu. Bukan hanya komponen-komponen masyarakat yang menjadi perhatian dalam pendekatan dialektika, tetapi terkait historis masyarakat juga menjadi perhatian dalam pendekatan dialektika ini. Sejarah juga menjadi penting dalam pendekatan dialektika, karena memahami masa silam adalah membantu untuk memahami apa yang terjadi di masa kini.

\section{Pesantren : Salaf vs Salafi}

Istilah pesantren, meminjam pemikiran Huseein Nasr (Azyumardi Azra, 1999) adalah lembaga pendidikan tradisional Islam yang mewarisi dan memelihara 
keberlangsungan tradisi Islam dari para ulama, yang tidak dibatasi oleh periodesasi. Tetapi dalam dunia pesantren, terdapat istilah pesantren salaf dan salafi, yang keduanya memiliki dimaknasi secara berseberangan. Azyumardi Azra memberikan pembeda tentang salaf dan salafi.

“...Istilah salaf bagi kalangan pesantren mengacu kepada pengertian pesantren tradisional yang justru sarat dengan pandangan dunia dan praktek Islam sebagai warisan sejarah, khususnya dalam bidang syari'ah dan tasawuf. Pada pihak lain, dalam pengertian lebih umum, kaum Salafi adalah mereka yang memegang paham tentang "Islam yang murni" pada masa awal yang belum dipengaruhi bid'ah dan khurafat. Karena itulah kaum salafi di Indonesia sering menjadikan pesantren dan dunia Islam tradisional lainnya sebagai sasaran kritis keras mereka, setidaknya karena keterkaitan lingkungan pesantren atau kiai dengan tasawuf dan tarekat. Bagi kamu salafi umumnya, tasawuf dan tarekat merupakan pandangan dunia dan pengamalan Islam yang bercampur dengan bid'ah dan khurafat..."

Salaf dan salafi inilah menjadi bagian dari persinggungan yang keras, yang sampai sekarang belum bisa bertemu. Pondok pesantren salaf, menjunjung toleransi, sebaliknya salafi mengkrik tindakan para kiai pondok salaf sebagai bentuk ketidakmampuan melawan Barat. Abdurrahman Wahid (Gus Dur) menjelaskan, pondok pesantren merupakan lembaga kultural yang menjadikan budaya Jawa sebagai simbol-simbolnya.

Tidak hanya itu, pesantren juga sebagai lembaga yang memerankan diri sebagai agen pembaharuan, dengan membawa gagasan pedesaan (rural development), juga sebagai pusat kegiatan belajar masyarakat (centre of community learning). Juga menjadi lembaga pendidikan yang bersandar pada silabi, yang dibawakan oleh intelektual musli Imam Jalaluddin Abdurrahman AlSuyuthi lebih dari 500 tahun silam. Menurut Abdurrahman Wahid (2006), nama lengkap Jalaluddin Abdurrahman Al-Suyuthi adalah Abu al-Fadl Abdur Rahman b. Abu Bakar b. Muhammad Jalaluddin as-Suyuthi. Ulama yang sangat produktif dalam membuat karya tulis ini dilahirkan di Kairo, 1 Rajab 849/3 Oktober 1445. As-Suyuthi hidup pada masa Dinasti Mamluk pada abad ke 15 dan memulai aktifitas menulisnya sejak usia 17 tahun. Tidak kurang dari 571 buku telah dihasilkan, mulai dari buku dengan halaman sedikit dan buku dengan halaman banyak. Bukunya yang terkenal di dunia pesantren adalah al-Asbah wa an-Nazair fi Qawa'id wa Furu' Fiqh asy Syafi 'i. Dalam kitab ini dijelaskan tentang contoh 
penerapan dan kandungan al-Qawa'id al-Khamsah yang selama ini berlaku bagi mazhab Syafi'i.

Abdurrahman Wahid menambahkan, ruang lingkup pengajaran oleh pesantren lebih luas dibanding sekolah formal. Jika sekolah formal hanya mengajari siswanya, beda dengan pesantren selain mengajari siswanya (santrinya) juga mengajari masyarakat tentang keislaman. Pesantren selain mengajarkan tentang keislaman kepada para santrinya di dalam komplek pesantren, juga mengajarkan agama kepada masyarakat melalui pengajian atau arisan di kampung-kampung tempat masyarakat tinggal.

Mun'im A. Sirry (2003) menambahkan, pesantren menempati tempat yang sangat strategis untuk membentuk budaya masyarakat, pengembangan budaya, bahkan politik. Dari sisi politik, pesantren juga mendapatkan perannya, bukan hanya di era sekarang tetapi pesantren di awal-awal pendiriannya(masa walisongo) juga memiliki peran penting dalam dunia politik. Beberapa walisongo di tanah Jawa, selain menjadi pemuka agama juga menjadi penggagas berdirinya kerajaan-kerajaan Islam.Imam Bawani (2011) mengatakan, sejarah mencatat, bahwa Sunan Giri merupakan tokoh dibalik berdirinya kesultanan Islam Demak Bintoro di Jawa Tengah. Pesantren yang berdiri sejak zaman Islam masuk di pulau Jawa itu, pertama kali menjadi pusat-pusat penyebaran Islam yang merupakan sumbangan dari sistem pembelajaran yang bermula dilaksanakan di masjid-masjid secara berkelompok berdasarkan diversivikasi aliran sehingga mengkristal menjadi aliran-aliran agama.

Pesantren dari masa ke masa menunjukkan perubahan demi perubahan, mulai dalam mengambil jarak atau sebaliknya mendekat ke ranah politik. Terutama terlihat perubahan dalam ranah politik, ketika masa pemerintahan Orde Baru dengan masa Presiden KH Abdurrahman Wahid. Sebagian besar pesantren di tanah air masa pemerintah Orde Baru mengambil jarak untuk tidak berkomunikasi kalau tidak disebut tidak mendukung pemerintahan Orde Baru. Sebaliknya pada masa Presiden RI, KH. Abdurrahman Wahid, pesantren mengambil posisi yang mendukung pemerintahan, tidak seperti masa Orde Baru. Masa presiden $\mathrm{KH}$ Abdurrahman Wahid, pesantren secara umum mendukung Abdurrahman Wahid, terutama pesantren yang memiliki latar belakang NU. 
Sedangkan hubungannya dengan agama-agama non muslim, pesantren juga mengambil peran penting, termasuk salah satunya adalah banyak kiai (pengasuh pesantren) terlibat langsung menjadi pengurus Forum Komunikasi Umat Beragama.

Pesantren menjadi bahan pembicaraan berskala nasional dan internasional terutama pasca terjadinya peristiwa bom di Legian, Bali pada 12 Oktober 2002 atau dikenal dengan peristiwa Bom Bali I, dengan jumlah korban tidak kurang dari 200 nyawa melayang. Para korban bukan hanya berasal dari Indonesia, tetapi dari berbagai negara, termasuk salah satunya negara tetangga, Australia. Oleh Abdurrahman Wahid (2006) disebut sebagai peristiwa yang menggiring pada identifikasi minor bahwa potret Islam fundamentalis lebih menjadi obyek kajian yang menarik. Penyebutan pesantren oleh Jusuf Kalla, memantik reaksi para akademisi dan peneliti untuk mengetahui lebih dalam tentang pesantren yang disebut-sebut menyebarkan radikalisme, tidak sedikit peneliti luar negeri yang mendatang lokasi pesantren, termasuk pesantren yang menjadi obyek penelitian kali ini (Al Islam di Tenggulun, Kecamatan Solokuro, Lamongan dan Al Ikhlas di Sedayu Lawas, Kecamatan Brondong, Kebupatan Lamongan).

Pendidikan pesantren sebenarnya memiliki tujuan mulia. Bagi Zamakhsyari Dhofier (1996), tujuan itu diantaranya untuk meninggikan moral santri, melatih dan meninggikan semangat santri, menghargai nilai-nilai spiritual dan kemanusiaan, mengajarkan kejujuran dan moral, dan menyiapkan santri untuk hidup sederhana. Pesantren tidak pernah mengajarkan perebutan kekuasaan, uang dan keagungan yang bersifat duniawi, dan hanya mengajarkan pola pengabdian kepada Tuhannya sebagai tujuan akhir dari semua pembelajaran di pesantren.

Melihat tujuan tersebut, seharusnya pesantren melahirkan orang-orang yang bermoral, tidak radikal, santun dan jujur. Tetapi sekarang sebagian kecil pesantren dituding menempati posisi berbeda dengan pesantren-pesantren pada umumnya, dengan mengambil peran jihad dengan pola radikal. Jika dalam dugaan awal ini ini demikian halnya, maka pesantren setidaknya bisa dikelompokkan menjadi dua kutub, yaitu kutub kanan merupakan kutub yang ditempati pesantren yang mengajarkan kedamaian, keharmonisan, paham moderat, dan inklusif. Sedangkan di kutub kiri ditempati pesantren yang mengajarkan kekerasan, radikalisme, dan 
eklusif dalam mencapai tujuannya. Islam radikal telah masuk ke mana-mana, termasuk ke lingkungan pesantren. Greg Barton dalam Ngainun Naim (2016), mengutip perkataan Abdurrahman Wahid, bahwa Islam radikal telah masuk ke mana-mana dan sudah sangat berbahaya. "Mereka mudah mengecoh banyak umat Islam dan mudah pula menyusup ke mana-mana dan kapan saja”.

\section{Radikalisme}

Radikalisme adalah paham atau aliran yang menginginkan perubahan dengan cara keras dan drastis. Radikalisme bukan hanya dilakukan oleh orang muslim, tetapi agama lain dengan mengatasnamakan agama juga mengalami hal serupa, yang disebut lainoleh Karen Amstrong (Al Jilani: 2014), dengan nama fundamentalisme. Karen Amstrong mengatakan:

"Fundamentalisme-baik Yahudi, Kristen, maupun Islam-jarang muncul dengan pertarungan dari luar, ia biasanya bermula dari sebuah pergulatan internal agama mereka sendiri di mana kaum tradisionalis memerangi kawan-kawan seagama mereka sendiri yang cenderung sekuler..."

Tinjauan Amstrong tentang radikalisme. Pertama, ideologi gerakan radikalisme bermula dari ketakutan oleh paham sekularisme yang mengancam pelenyapan mereka. Ketakutan itu berbuah tindakan defensive pada awalnya, dengan membuat sederet penangkal, berupa rumusan-rumusan doktrin, pembatasan-pembatasan dan membuat penghalang. Dunia modern yang liberal dianggap sebagai sesuatu yang mengancam karena dunia modern yang liberal itu dinilai tidak bertuhan. Kedua, gerakan radikalisme dinilai bukanlah gerakan kuno, tetapi gerakan yang mampu beradaptasi dengan zamanya, gerakan modern yang adaptif, inovatif dan mampu membaca dasar-dasar keagamaan dengan menggunakan rasional. Amstrong mencontohkan dari sudut pandang sosiologi keagamaan tentang pengekangan agama yang melahirkan fundamentalisme di Turki, Mesir, dan Iran. Pemerintah sekuler Turki yang dipengaruhi Barat, mamaksa masyarakatnya menutup madrasah dan meniru budaya asing. Kebijakan pemerintah Turki ini tentu menjatuhkan otoritas ulama yang selama ini sebagai pendiri madrasah. Berawal dari sinilah, fundamentalisme di Turki muncul untuk melakukan perlawanan terhadap pemerintah yang memiliki kebijakan tidak memihak kepada ulama. 
Sedangkan tumbuhnya radikalisme di Indonesia setidaknya eksistensinya menguat adalah pasca reformasi, ditandai dengan jatuhnya Presiden Soeharto dari kursi kepresidenan. Pada masa Soeharto, Ariel Hariyanto dalam Ngainun Naim (2016), mengatakan Islam fundamentalis tidak sempat muncul, karena pemerintah sangat kuat kehadirannya untuk melakukan penekanan terhadap muncul Islam fundamentalis. Tetapi ketika ruang ekspresi terbuka lebar di saat reformasi, kelompok Islam radikal memanfaatkannya dengan sebaik mungkin. Padahal keberadaan Islam radikal sesunggunya tidak menguntungkan, karena ketika kelompok ini tumbuh, aksi mereka akan menghambat pembangunan. Fenomena tumbuhnya Islam radikal ini sebenarnya sejak lama diprediksi oleh sejumlah pakar sosial keagamaan. Salah satunya adalah R. William Liddle dalam Mark R Woodward (1999) mengatakan bahwa keterbukaan politik yang terjadi pada erareformasi merupakan keberhasilan demokrasi, tetapi sisi lain menumbuhkan kelompok Islam skriptualis. Kelompok ini bukan melakukan gerakan intelektual, tetapi kelompok Islam skriptualis adalah kelompok yang berorientasi pada penerapan Islam yang sudah termaktub dalam Al-Qur'an dan Hadis yang berorientasi pada penegakan syari'at.

\section{Genealogi Radikalisme di Indonesia}

Menurut Saifuddin (2015), awal mula radikalisme di Indonesia, sebenarnya bisa dilacak jauh ke belakang sebelum peristiwa Bom Bali I, yaitu pada tahun 1949 di mana Kartosuwiryo mendeklarasikan Negara Islam (NI) dan Tentara Islam Indonesia (TII). Deklarasi ini terus mengalami perkembangannya, pada tanggal 20 Januari 1952, Kartosuwiryo mendapat suntikan dukungan dari Kahar Muzakkar bersama pasukannya di Sulawasi, kemudian disusul Daud Beureueh di Aceh pada tanggal 21 September 1953. Termasuk dukungan dari Ibnu Hajar dan pasukannya di Kalimantan Selatan. Tetapi ketegasan pemerintah RI, membuat Kartosuwiryo dan pengikutnya harus menghentikan gerakannya yang semula dilakukan dengan cara terang-terangan, dan diganti dengan gerakan-gerakan di bawah tanah.

Bahkan bagi Suprihatiningsih (2012), gerakan radikal di Indonesia ini masih terus berkembang dengan bentuk keragamannya, mulai dari jalur pendidikan, jamaah pengajian, sampai pada halaqoh-halaqoh di perguruan tinggi, 
termasuk di pesantren. Termasuk dalam mengambil posisi jihadnya, sebagian mengambil jihad dalam wilayah syar'i tanpa fokus pada pendirian negara Islam (khilafah), tetapi sebagian lain konsentrasi pada wilayah politik dengan bercitacita mendirikan negara Islam (khilafah) di seluruh belahan dunia.

\section{Metode Penelitian}

Penelitian ini menggunakan pendekatan deskriptif kualitatif (qualitative descriptive design). Taylor dalam Dedy Mulyana dan Solatun (2008) menjelaskan bahwa yang dimaksud kualitatif adalah penelitian yang bersifat interpretif (menggunakan penafsiran) yang melibatkan banyak metode dalam menelaah masalah penelitiannya. Secara konvensional, metode kualitatif cenderung diasosiasikan dengan keinginan peneliti untuk menelaah makna, konteks, dan suatu pendekatan holistic terhadap fenomena yang melahirkan data deskriptif berupa kata-kata tertulis atau lisan dari orang-orang dan perilaku yang dapat diamati. Untuk mengumpulkan data, dalam penelitian ini mengandalkan pengamatan (observation) terhadap obyek penelitian dan wawancara mendalam (indepth interview) terhadap informan sebagai intrumen untuk menghasilkan data deskriptif. Diantara informannya adalah pengasuh pesantren dan ustadz pesantren.

Teknik analisis data kualitatif ini bersifat induktif yaitu analisis yang berdasarkan data yang diperoleh kemudian melahirkan sebuah hipotesa dengan menggunakan teknik analisis naratif.

\section{Hasil Penelitian}

Pelaku radikalisasi adalah terdiri dari orang-orang terdidik, bisa terpelajar dari pendidikan umum atau santri pondok pesantren. Selain itu, berasal dari daerah yang terfokus di beberapa titik di tanah air, misalnya meraka berasal dari daerah Solo dan Lamongan. Nama Lamongan di dunia internasional, terutama di dunia ke-imigrasian menjadi perhatian tersendiri, misalnya ketika hendak mengizinkan warga Lamongan masuk ke negara tertentu, terutama terkait dengan terorisme, mereka akan mendapatkan perhatian serius. Hal ini disampaikan Hamam, seorang warga Blimbing, Kecamatan Paciran, Kabupaten Lamongan. (Hamam, Wawancara, di kediamannya pada 19 Januari 2017). 
Tidaklah terlalu salah dunia internasional mewaspadai wilayah Kabupaten Lamongan, karena tidak sedikit pelaku radikalisasi berasal dari Lamongan, terutama dari daerah Kecamatan Paciran dan Solokuro. Dari hasil riset, tercatat sedikitnya terdapat 22 warga Desa Blimbing, Kecamatan Paciran, Kabupaten Lamongan sudah masuk di negara Syiria dan menggabungkan diri menjadi anggota Islamic State of Iraq and Syiria (ISIS), bahkan terdapat satu diantaranya yang menjadi komandan pasukan. Pada tahun 2014 silam, mereka berangkat untuk memperkuat pasukan ISIS di Syiria bersama keluarganya.

Bukan hanya radikalisasi di tingkat internasional, menurut Hamam (Salah satu ketua RT di Desa Blimbing) dua orang warga Kelurahan Blimbing juga terlibat dalam pengeboman di Indonesia. Pertama pelaku bom bunuh diri di Poso pada tanggal 3 Juni 2013 adalah Zainul Arif (usia 34 tahun) atau dikenal akrab dengan sebutan Arif Petak (warga Kelurahan Blimbing). Kedua, Rizal yang asli Sumatra dan nikah dengan perempuan asal Kelurahan Blimbing juga terlibat pengeboman di Tulungagung pada tanggal 22 Juli 2013. Belum lagi sikap radikal yang terjadi di wilayah Kelurahan Blimbing dan sekitarnya, banyak persinggungan social terutama terkait dengan agama yang menimbulkan pengeroyokan dan tindak kekerasan.

\section{Dari Ngruki Mengakar di Pantai Utara Lamongan}

\section{a. Pesantren Al Islam Tenggulun}

Pesantren ini dikenal sebagai pesantren milik keluarga Amrozi, otak dibalik peristiwa Bom Bali I. Amrozi adalah alumni pesantren Al Mukmin Ngruki, yang kemudian mendirikan pesantren Al Islam bersama saudara-saudaranya. Beberapa alumnus yang kemudian menjadi ustadz di pesantren itu pernah terlibat aksi teroris, diantaranya Iswanto, siswa yang sejak nyantri akrab dengan Ali Imron itu pernah membantu teroris di Poso dan membantu mengirimkan alat pembuatan bom saat Bom Bali I. Ia kini telah bertaubat dan berstatus sebagai guru Madrasah Ibtidaiyah bersertifikasi di tempat kelahirannya di Karangbinangun, Kabupaten Lamongan.

Selain Siswanto, terdapat nama Arif yang pernah ditahan karena terlibat menyimpan beberapa pucuk senjata dan mengantarkan ke Jakarta dua orang yang 
hendak masuk Syiria untuk bergabung ke ISIS. Arif tidak lama nyantri di Al Islam Tenggulun, kira-kira kisaran hanya setahun. Tetapi dari nyantri setahun itu, Ia memperoleh pengalaman yang tidak didapat sebelumnya, sehingga pemuda asal sebuah desa di Jatirogo, Kabupaten Tuban itu menjadi pemuda yang garang dan radikal.

Bukan hanya Iswanto dan Arif, masih ada contoh lain dari santri Al Islam Tenggulun, yaitu Sumarno, yang dipenjara karena terlibat membantu menyembunyikan ribuan pucuk senjata di tengah hutan Dadapan pasca peristiwa Bom Bali I. Sedangkan dari keluarga pesantren Al Islam Tenggulun yang terlibat terorisme dan dijatuhi hukuman adalah Ali Fauzi dan Ali Imron (dipenjara), sedangkan Amrozi dan Ali Ghufron (selain dipenjara juga telah dihukum mati di depan regu tembak).

Apakah ini berarti pesantren Al Islam dan Al Mukmin Ngruki, merupakan pesantren yang mengajarkan radikalisme. Belum tentu, dengan dalih bisa saja pengalaman terorisme itu diperoleh dari luar pesantren setelah lulus. Tetapi bisa juga dikatakan bahwa Al Islam memang melahirkan kader-kader militan untuk menjadi teroris, dengan bukti empiris bahwa nama-nama pelaku teroris tersebut adalah dari keluarga dan ada juga yang santri pesantren Al Islam. Bagaimana sebenarnya kurikulum yang diajarkan, jika dilihat kasat mata kurikulum tertulis yang diajarkan dipastikan tidak melanggar norma-norma dan tidak mengajarkan radikalisme, tetapi jika dilihat dari hidden curriculum (kurikulum tersembunyi), bisa saja muncul pendorong untuk melakukan tindakan radikalisme.

Iswanto yang diwawancarai peneliti, menyebutnya, bahwa di pesantren $\mathrm{Al}$ Islam Tenggulun, dirinya selama nyantri selalu diajarkan oleh para pengasuh tentang perlunya jihad dan dakwah. Kalimat penyemangat atau doktrin yang sering disampaikan para pengasuh diantaranya, berbunyi. "Isy karîman aw mut syahîdan" (hidup mulia atau mati syahid).

Dari hasil wawancara dan penglihatan secara empiris, peneliti bisa mengambil sebuah kesimpulan, bahwa jika dilihat dari banyaknya orang-orang pesantren Al Islam Tenggulun dan sedikit dari penuturan Iswanto tentang doktrin yang diterimanya saat masih berstatus santri, pesantren Al Islam Tenggulun telah melahirkan orang-orang militan. Peneliti tidak bisa menyebutnya apakah 
pesantren Al Islam Tenggulun ini menjadi lembaga untuk mengajarkan radikalisme atau tidak. Tetapi peneliti hanya bisa sampai pada sebuah kesimpulan bahwa pesantren milik keluarga Amrozi ini telah melahirkan orang-orang militan.

Amrozi dianggap sebagai sosok fenomenal bagi santri Al Islam Tenggulun yang kemudian banyak diikut jejaknya oleh para santri Tenggulun. Amrozi diputus majlis hakim dengan hukuman mati. Pria asal Desa Tenggulun, Kecamatan Solokuro berjarak sekitar 55 KM dari kota Lamongan, mati di hadapan regu tembak. Tetapi sesaat setelah hukuman tembak Amrozi dilakukan, terutama saat penguburan, terjadi pro-kontra tentang matinya Amrozi, sebagian muslim mengatakan, Amrozi sebagai 'sahid' (meninggal yang membela agama Allah dan dijanjikan surga oleh Allah). Pendapat ini keluar dari bibir para santri dan pesantren yang sehaluan dengannya. Sedangkan yang lain mengatakan Amrozi diistilahkan dengan bahasa yang agar miris untuk diucapkan, yaitu mati sangit (mati yang tidak baik atau su al-khotimah). Terlepas dari itu semua, berarti terjadi pro kontra tentang tindakan yang dilakukam Amrozi, sebagian setuju tentang tindakan terorisme yang dilakukan Amrozi dan sebagain besar muslin lain menyatakan menolak tindakan Amrozi dengan dalih kemanusiaan.

\section{b. Pesantren Al Ikhlas Sedayu Lawas}

Pesantren Al Ikhlas adalah pesantren yang berdiri di desa Sedayu Lawas, Kecamatan Brondong, Kabupaten Lamongan. Pendiri dan pengasuhnya adalah Ashari Dipo Kusumo. Ia santri di pesantren Al Mukmin Ngruki, Solo dan setelah dianggap mampu, Dipo diminta membantu mengajar di pesantren sama, Al Mukmin. Tidak berselang lama, Dipo dikirim ke desa Tenggulun untuk membantu mengajar di pesantren Al Islam, Tenggulun. Di tengah-tengah mengajar di Al Islam Tenggulun, sebagian masyarakat Sedayu Lawas meminta agar Dipo pindah ke Sedayu Lawas dan diberikan lahan untuk mendirikan pesantren. Atas permintaan itu, Dipo harus pindah ke Sedayu Lawas dan mendirikan pesantren Al Ikhlas. Pria kelahiran Bandung, 9 Oktober 1968 dan dibesarkan di Jakarta, sering berpindah-pindah tempat mengikuti ayahnya bertugas sebagai TNI Angkatan Darat (dulu: bernama Angkatan Bersenjata Republik Indonesia--ABRI).

Dipo kepada peneliti (Wawancara peneliti kepada Ashari Dipo Kusomo, pada tanggal 23 Januari 2017 di kediamannya Desa Sedayu Lawas, Kecamatan 
Brondong, Kabupaten Lamongan), mengaku dirinya banyak menimba ilmu dari pesantren Al Mukmin Ngruki, yang diasuh oleh Ustadz Abu Bakar Ba'asyir. Saat ditanya tentang keterlibatan pesantren Al Ikhlas dengan radikalisme, Dipo mengatakan:

"Saya tahu, orang-orang sekitar sini (wilayah Brondong dan sekitarnya) menganggap bahwa pesantren ini mendidik para santri untuk bertindak radikalis. Saya ingin menjelaskan, bahwa pesantren ini hanyalah merupakan pesantren untuk menghafal al-Qur'an. Pesantren ini khusus untuk perempuan (saat peneliti melakukan riset)".

Bahkan saat peneliti melakukan cross check, terhadap pengakuan Dipo bahwa pesantren Al Ikhlas tidak mengajarkan teroris terdapat penjelaskan dari informan (disembunyikan identitasnya) yang kontra dengan penjelasan Dipo. Misalnya, informan diambil dari salah satu ketua RT di desa Blimbing, Kecamatan Paciran, Lamongan, Ketua RT tersebut (identitas dirahasiakan untuk keselamatannya), mengatakan bahwa pemuda-pemuda Blimbing yang terlibat aksi teros di beberapa tempat, termasuk masuk jaringan ISIS adalah mereka masih berstatus santri kalong (santri yang tidak bermukim di pesantren, tetapi mereka ikut ngaji di pesantren Al Ikhlas). Terdapat sedikitnya 20 pemuda Blimbing masuk Syiria dan bergabung dengan ISIS. Selain itu, peneliti saat hendak wawancara kepada Dipo, juga mendapatkan peringatan dari seorang anggota polisi agar berhati-hati dan tidak terpengaruh atau masuk radikalisme karena pengaruh Dipo.

Temuan empiris oleh peneliti dari dua informan tersebut, sekaligus menguatkan pendapat Dipo bahwa sampai sejauh ini masyarakat masih mencurigai pesantren Al Ikhlas sebagai pesantren yang mengajarkan radikalisme. Saat peneliti menanyakan kepada Dipo tentang tanggapan masyarakat terhadap pesantren Al Ikhlas seperti itu, Dipo membenarkan. Menurut Dipo, memang sampai sejauh ini masyarakat masih membuat penilaian bahwa pesantren $\mathrm{Al}$ Ikhlas mengajarkan radikalisme.

Tapi Dipo mengatakan bahwa pesantren yang diasuhnya itu sama sekali tidak mengajarkan tentang radikalisme, hanya mengajarkan membaca dan menghafal Al-Qur'an. Saat peneliti datang ke kediamannya, Dipo dengan sangat senang hati menjelaskan posisi pesantrennya, bahkan terjadi dialog panjang dalam 
satu pertemuan (sekitar empat jam) antara peneliti dan Dipo, meski pertemuan antara peneliti dengan Dipo baru pertama kali dan sebelumnya tidak pernah kenal antara Dipo dan peneliti.

\section{Radikalme dan hidden curriculum pengasuh pesantren}

Menurut Hamam radikalisme yang memapar para pemuda Blimbing ini tidak lepas dari kehadiran pengasuh pondok pesantren Ngruki, Abu Bakar Baasir beberapa tahun sebelumnya ditambah dengan kehadiran pondok pesantren yang berafiliasi ke Pondok Pesantren Ngruki, yaitu pesantren Al Ikhlas di Sedayu Lawas. Tetapi pengasuh pesantren Al Ikhlas, Ust. Dipo mengaku kepada peneliti, bahwa pesantrennya memang disorot secara negatif oleh masyarakat sekitar dan dianggap mengajarkan radikalisme. Dipo mengakui bahwa pesantren yang diasuhknya tidak mengajarkan radikalisme.

Tetapi dari hasil wawancara dengan peneliti selama beberapa jam terkait pemikiran ust. Dipo tentang "khilafah" dan radikalisme di Indonesia menjadi sebuah keniscayaan. Bagi Dipo, "khilafah" harus diperjuangkan, karena Dipo menyakini sebuah hadis Nabi, bahwa di dalam Islam terdapat fase kepemimpinan, dari fase Rasululullah, khalifah, raja, kemudian ada masa fathrah (kosong), tidak ada kepemimpinan), dan kembali lahir khalifah. Sekarang ini masa fathrah yang sedang diperjuangkan agar terisi pemimpin Islam secara internasional. Meskipun dari kurikulum tertulis tidak tampak mengajarkan radikalisme, tetapi hidden curriculum (kurikulum tersembunyi) yang menjadi pemikiran pengasuh pesantren, diyakini akan sampai (baik senjaga ataupun tidak sengaja) kepada para santri di forum resmi (mengaji/belajar) ataupun forum tidak resmi (di luar waktu belajar).

Dari data empiris, selain pesantren Al Ikhlas, terdapat di pesisir utara Lamongan model pesantren yang inklusif dan moderat. Misalnya di pesantren Tarbiyatuth Tholabah di Desa Kranji, Paciran yang diasuh oleh KH. Nasrullah Baqier dan Pesantren Sunan Drajat di Desa Drajat, Kecamatan Paciran, Lamongan yang diasuh KH. Abdul Ghofur. Dua pesantren ini tergolong pesantren yang tidak kaku dan sebaliknya mengajarkan sikap toleransi.

Dari sisi kurikulum, peneliti mengambil salah satu kitab yang biasa dikaji, yaitu kita nasaihul 'ibad, karya Syekh Hajar al Asykalani yang disyarahi Imam Nawawi al Bantani. Dalam kita yang diajarkan kepada santri ini berisi tentang 
selain mengagungkan kepada Allah SWT, juga mengajarkan tentang manusia menghormati kepada manusia lain atau manusia bermanfaat kepada manusia lain. Bukan hanya itu, dalam beberapa pengajian para kiai dan gurunya juga mengajarkan sikap toleransi.

\section{E. Pembahasan}

Pengasuh pesantren (Jawa: Kiai) menjadi bagian penting dalam fokus penelitian pesantren, karena kiai adalah sosok yang tidak bisa dilepaskan dari pesantren, ke mana pondok pesantren itu diarahkan tujuannya, tergantung bagaimana kiai memiliki visi dan misi dalam membangun pendidikannya. Meminjam istilah Clifford Geertz (dalam Abdurrahman Wahid, 2006) bahwa kiai pondok pesantren dinilai sebagai cultural broker (makelar budaya). Kesimpulan Geertz demikian, karena kiai pesantren telah melakukan fungsi screening terhadap setiap budaya di luar masyarakat yang diasuhnya. Jika budaya itu cocok, maka bisa diambil, tetapi jika budaya itu dinilai tidak cocok maka peluang terbesar ditolak oleh kiai pesantren.

Pendapat Geertz ini bisa dikatakan bahwa perilaku masyarakat yang tinggal di pesantren dan sekitarnya sedikit banyak akan dipengaruhi oleh budaya pesantren, dalam hal ini kiai atau ustadz sebagai figure panutan masyarakat, baik masyarakat yang tinggal di dalam pesantren (santri) maupun masyarakat yang tinggal di luar pesantren. Dengan kata lain, ketika masyarakat sekitar pesantren itu harmonis atau tidak harmonis dalam hidupnya, maka patut untuk dilihat pesantren di sekitarnya.

Tidak heran ketika masa pemerintah Orde Baru, pesantren diharapkan memerankan fungsinya sebagai agen perubahan pada masyarakat dan pembangunan masyarakat. Bagi Azyumardi Azra (1999) pesantren bukan hanya diharapkan menjadi pemeran dalam fungsi-fungsi tradisionalnya, yakni pemeliharaan tradisi-tradisi Islam, transmisi dan transfer ilmu-ilmu Islam, dan melakukan reproduksi ulama, tetapi lebih dari itu juga menjadi tumpuan agen perubahan pada masyarakat.

Jika proposisi yang dibangun sesuai dengan pendapat Geertz, "Kiai sebagai agen budaya." maka proposisi itu bisa pada sebuah kongklusi bahwa radikalisme 
yang memapar kepada para santri atau "mantan" santri termasuk bagian yang tidak bisa dipisahkan dari kiai. Termasuk jika di masyarakat terjadi antiradikalisme, inklusif, dan moderat, maka itu termasuk bagian tak terpisahkan dari pesantren (kiai). Maka dalam hal ini, kiai dan pesantren bisa menjadi inspirator kepada masyarakat di sekitarnya untuk menjadi radikal atau sebaliknya kiai dan pesantren juga bisa menjadi inspirator kepada masyarakat sekitar untuk memiliki paham radikal.

Dialektika pesantren dan radikalisme agama memang sampai sekarang sedang subur-suburnya menjadi perbincangan di Indonesia. Pemaknaan yang skriptualis terhadap ajaran agama oleh kiai atau pengasuh pesantren yang kemudian ditranformasikan kepada para santrinya, menjadi penyebab pesantren dan radikalisme seperti dua mata uang yang tidak pernah dipisahkan (interaksi yang tidak pernah berhenti antara pesantren dan radikalisme). Tentu hal ini tidak semua kiai memaknai agamanya dengan pendekatan skriptualis, tetapi jauh lebih banyak jumlah kiai atau pengasuh pesantren yang memaknai agamanya dan mentranformasikannya kepada para santrinya dengan pendekatan kontekstual.

Pemaknaan agama dengan pendekatan skriptualis menyebabkan individu tidak mau menerima bentuk agama orang lain. Bagi individu model seperti ini yang menjadi pemikirannya adalah kebenaranyang dimilikinya adalah agama dan keyakinannya sendiri, sementara agama dan keyakinan orang lain salah dan harus diperangi. Misalnya term "jihad" bagi orang-orang skriptualis, berarti perang dengan mengangkat pedang atau senjata, tetapi bagi kontektualis, "jihad" bisa bermakna berjuang di jalan ilmu, bukan peperangan. Pendidikan dalam hal ini pesantren menempati tempat yang sangat strategis dalam mencipatkan radikalisme maupun antiradikalisme. Pengasuh dan guru menjadi orang terdepan dalam mengembangkan idiologi-idiologi ini. Tidak heran, Robert Hefner (Muhibat: 2015) pernah melakukan riset terhadap guru di delapan propinsi di Indonesia. Mereka dimintai tanggapan tentang bentuk negara. 85,9 \% dari 940 responden sepakat demokrasi merupakan bentuk terbaik di Indonesia, namun pada saat yang sama terdapat $64,4 \%$ responden mendukung penarapan shari'ah Islam.

Menurut Edward W, Said (Muhibat, 2015), pendidikan sepatutnya menjadi bagian dari intrumen yang mendasar sebagai media pembentukan karakter bangsa 
di tengah heterogenitas dan pluralitas yang menjadi karakter bangsa Indonesia. Di tengah perbedaan ras, suku, agama, seharusnya pendidikan (baik pendidikan formal, maupun pendidikan pesantren) seharusnya menempatkan diri menjadi pendorong untuk mencipatakan akulturasi dari semua perbedaan, sehingga mampu meminimalisir perbedaan di tengah-tengah heteroginitas kehidupan bangsa Indonesia. Edward Said melihatnya radikalisme bukan sekedar wilayah fisik, tetapi sudah masuk ke wilayah pendidikan dengan perang gagasan untuk merebut hati dan pikiran masyarakat. Inilah dialektika yang tergambar antara pesantren dan radikalisme di Indonesia.

Jika dilihat dari temuan emperis, maka setidaknya terdapat dua bentuk pesantren di Indonesia yaitu pesantren yang bersikap ekslusif, radikal dan melahirkan santri-santri yang bergerak pada terorisme. Tapi juga terdapat pesantren yang menempati posisi berseberangan dengan mengajarakan inklusif, moderat dan menjunjung tinggi nilai-nilai toleransi.

\section{F. Kesimpulan}

Pesantren sebagai lembaga pendidikan memiliki andil besar terhadap perilaku santrinya, apakah santri akan menjadi moderat atau radikal sedikit banyak dipengaruhi oleh pengalamannya. Pengalaman itu bisa berasal dari keluarganya atau pengalamannya itu berasal dari lingkungan pendidikannya. Dalam dunia pendidikan, kiai, pengasuh dan guru, menjadi sosok yang banyak diteladani dan banyak dijadikan bahan tiruan internalisasi perilaku santri. Dalam kurikulum pesantren (kurikulum tertulis) tidak mengajarkan A, tetapi hasil bisa A, karena di pesantren kurikulum tersembunyi (hiddeen curriculum) paling dominan memberikan pengaruhnya kepada para santri. Kiai, pengasuh, guru, ustadz, secara sadar atau tidak sadar telah memberikan pengaruhnya (dalam perilakunya) terhadap setiap para santrinya. Itulah yang oleh Geerts disebutkan sebagai kiai bisa membentuk kultur masyarakat pesantren, termasuk para santri.

Maka bisa disimpulkan bahwa terjadi dialektika antara pesantren dan radikalisme. Tetapi seberapa besar pesantren memberikan pengaruhnya terhadap radikalisme, itu bisa dibahas pada tulisan berbeda, Yang pasti, melihat fakta emperis di Lamongan bisa dijelaskan bahwa dialektika pesantren dan radikalisme 
memang benar terjadi adanya. Dengan temuan ini, maka yang perlu diperhatikan oleh pemerintah adalah lebih memperhatikan pesantren, terutama pesantrenpesantren yang bisa diindikasikan sebagai pesantren yang mengajarkan radikalisme, baik secara langsung melalui kurikulum tertulis ataupun melalui hidden currikulum.

\section{Daftar Pustaka}

Al-Jilani, Abdul Karim. 2014. Perspektif Karen Armstrong Tentang Gerakan Muslim Fundamentalis di Abad Modern. Maraji', Vol. 1, No. 1, September.

Azra, Azyumardi. 1999. Pendidikan Islam, Tradisi dan Modern Menuju Milenium Baru. Jakarta: PT Logos Wacana Ilmu.

Bawani, Imam, dkk. 2011. Pesantren Buruh Pabrik, Pemberdayaan Buruh Pabrik Berbasis Pendidikan Pesantren. Yogyakarta: LKiS.

Carnetton, Paul, (ed).1976. Critical Sociology. Harmondsworth, Eng: Penguin.

Cassier, Meolong, J. 1993. Metodologi Penelitian Kualitatif, cetakan keempat. Bandung: PT Remaja Rosdakarya.

Dhofier, Zamakhsyari. 1996. Tradisi Pesantren. Jakarta: LP3ES.

Hamam, Ahmad. 2017. Ketua RT 02. RW 11 Kelurahan Blimbing di kediamannya. Wawancara. 10 Januari.

-----. 2017. Wawancara. 19 Januari.

Hefner, Robert W. 2009. Islamic School, Social Movement and Democracy in Indonesia. Dalam Robert W, Hefner, Making Modern Moslem: the Politics of Islamic Education in Southeast Asia (Honolulu: University of Hawai Press.

Iswanto. 2017. Wawancara, Lamongan 31 Juli.

Johnson, Doyle Paul. 1986. Sociological Theory Classical Founders and Contemporary Perspektives diterjemahkan Robert M.Z. Lawang, Teori Sosiologi Klasik dan Modern, Jilid I. Jakarta: PT Gramedia.

Karomani, Aom. 2018. Pesantren Radikal dan Anti-NKRI Harus Dibubarkan, http://www.nu.or.id/post /read/90342/pesantren-radikal-dan-anti-nkri-harusdibubarkan

Kosim, Muhammad. 2006. Pesantren dan Wacana Radikalisme, Karsa, Vol.IX No.1, April.

Kusmanto, Thohir Yuli, dkk. 2015. Dialektika Radikalisme dan Antiradikalisme di Pesantren. Walisongo, Vol. 23, No. 1, Mei.

Kusumo, Ashari Dipo. 2017. Pengasuh Pondok Pesantren Al Ikhlas di Sedayu Lawas, Kecamatan Brondong, Lamongan di kediamannya. Wawancara. 23 Januari.

Lauer, Robert H. 1989. Perspektif tentang Perubahan Sosial, ed. II, (terj), Alimandan, Jakarta: Binan Aksara,

Thohir Yuli Kusmanto, dkk. 2015. Dialektika Radikalisme dan Antiradikalisme di Pesantren. Walisongo, Volume 23, No. 1, Mei.

Manshur, Toha. 2017. Kepala Kelurahan Blimbing. Wawancara. 19 Januari.

Jurnal Darussalam; Jurnal Pendidikan, Komunikasi dan Pemikiran Hukum Islam Vol. XI, No 1:36-55. September 2019. ISSN: 1978-4767 (Cetak), ISSN: 2549-4171(Online)

Terakreditasi Nasional. SK. No.21/E/KPT/2018 
Milles, Metthew B. dan A. Michael Huberman. 2009. Analisis Data Kualitatif. Jakarta: UI Pres.

Muharom, Fauzi. 2015. Respon Pondok Pesantren Terhadap Problem Pencitraan di Media (Studi Pemulihan Citra Pondok Pesantren Islam al-Mukmin Ngruki Sukoharjo Surakarta, Disertasi: UIN Sunan Kalijaga.

Mukhibat. 2015. Memutus Mata Rantai Radikalisme dan Terorisme Berbasis Studi Etnopedagogi di PTNU dalam Membentuk Keberagamaan Inklusi dan Pluralis. Islamica, Vol. 10, No 1, September.

Mulyanan, Dedy dan Solatun. 2008. Metode Penelitian Komunikasi. Edisi kedua. Bandung: PT Remaja Rosdakarya.

Naim, Ngainun. 2016. Islam Radilal dan Strategis Deradikalisasi, Rekontruksi Pemikiran Abdurrahman Wahid, Proceeding, Annual International Conference on Islamic Studies-AICIS 2016 di IAIN Raden Intan Lampung, 1-4 November.

Ridlwan, Mujib. 2013. Revitalisasi Peran Profetik Pesantren Dalam Membendung Radikalisme Agama. Al Hikmah, Vol. 3, No. 1 , Maret.

Ritzer, George. Sociological Theory. 2014. (terJ) Saut Pasaribu, dkk, Teori Sosiologi, Dari Sosiologi Klasik Sampai Perkembangan Terakhir Posmodern. Yogyakarta: Pustaka Pelaar.

Said, Edward W. 2006. The Mind of Terrorism. USA: Booksmaxwell.

Saifuddin. 2011. Pergolakan Politik Islam, dalam Saifuddin, Radikalisme Islam di Kalangan Mahasiswa: Sebut Metaforsa Baru. Analisis, Vo XI, No. 1.

Sirry, Mun'im A. 2003. Membandung Militansi Agama, Iman, dan Politik dalam Masyarakat Modern. Jakarta: Penerbit Erlangga.

Sugiono. 2009. Metode Penelitian Bisnis. Bandung: Penerbit Alfabeta.

Sukmadinata, Nana Syaodih. 2010. Metode Penelitian Pendidikan, Cet. IV. Bandung: PT Remaja Rosdakarya kerjasama Program Pacasarjana Universitas Pendidikan Indonesia.

Sumarno. 2018. Wawancara, Lamongan 31 Juli.

Suprihatiningsih. 2012. Spiritualitas Gerakan Radikalisme Islam di Indonesia. Ilmu Dakwah, Vol. 32, No. 2, Juli.

Tempo.co.id/read/news/2004, Diunduh, 1 Januari 2017.

Wahid, Abdurrahman. Islamku-Islam Anda-Islam Kita: Agama Masyarakat Negara Demokrasi. Jakarta: The Wahid Institut. 